

\section{The Rise and Fall of the English Christendom}

English Christendom has never been a static entity. Evangelism, politics, conflict and cultural changes have constantly and consistently developed it into myriad forms across the world. However, in recent times that development has seemingly become a general decline. This book utilises the motif of Christendom to illuminate the pedigree of Anglican Christianity, allowing a vital and persistent dynamic in Christianity, namely the relationship between the sacred and the mundane, to be more fundamentally explored.

Each chapter seeks to unpack a particular historical moment in which the relations of sacred and mundane are on display. Beginning with the work of Bede, before focusing on the Anglo Norman settlement of England, the Tudor period, and the establishment of the church in the American and Australian colonies, Anglicanism is shown to consistently be a religiopolitical tradition. This approach opens up a different set of categories for the study of contemporary Anglicanism and its debates about the notion of the church. It also opens up fresh ways of looking at religious conflict in the modern world and within Christianity.

This is a fresh exploration of a major facet of Western religious culture. As such, it will be of significant interest to scholars working in Religious History and Anglican Studies, as well as theologians with an interest in Western Ecclesiology.

Bruce Kaye is an Adjunct Research Professor in the Centre for Public and Contextual Theology at Charles Sturt University, Australia, and was the General Secretary of the Anglican Church of Australia from 1994 to 2004. $\mathrm{He}$ is the author of $\mathrm{He}$ is the author of over 120 articles and papers including eight books and ten edited volumes.as well as contributing to newspapers, radio and TV. He has taught at various institutions around the world, and held Visiting Fellowships in Freiburg-im-Breisgau, Cambridge and Seattle, was also the founding editor of the Journal of Anglican Studies. 


\section{Routledge Contemporary Ecclesiology}

For a full list of titles in this series, please visit www.routledge.com

Series editors:

Martyn Percy,

University of Oxford, UK

D. Thomas Hughson,

Marquette University, USA

Bruce Kaye,

Charles Sturt University, Australia

The field of ecclesiology has grown remarkably in the last decade, and most especially in relation to the study of the contemporary church. Recently, theological attention has turned once more to the nature of the church, its practices and proclivities, and to interpretative readings and understandings of its role, function and ethos in contemporary society.

This series draws from a range of disciplines and established scholars to further the study of contemporary ecclesiology and publish an important cluster of landmark titles in this field. The series editors represent a range of Christian traditions and disciplines, and this reflects the breadth and depth of books developing in the Series. This series presents a clear focus on the contemporary situation of churches worldwide, offering an invaluable resource for students, researchers, ministers and other interested readers around the world working or interested in the diverse areas of contemporary ecclesiology and the important changing shape of the church worldwide.

Titles in the series include:

The Holy Spirit and the Church

Ecumenical Reflections with a Pastoral Perspective

Edited by Thomas Hughson

The Future Shapes of Anglicanism

Currents, Contours, Charts

Martyn Percy

Growth and Decline in the Anglican Communion

1980 to the Present

Edited by David Goodhew

The Rise and Fall of the English Christendom

Theocracy, Christology, Order and Power

Bruce Kaye 


\section{The Rise and Fall of the English Christendom}

Theocracy, Christology, Order and Power

\section{Bruce Kaye}


First published 2018

by Routledge

2 Park Square, Milton Park, Abingdon, Oxon OX14 4RN

and by Routledge

711 Third Avenue, New York, NY 10017

Routledge is an imprint of the Taylor \& Francis Group, an informa business

(c) 2018 Bruce Kaye

The right of Bruce Kaye to be identified as author of this work has been asserted by him in accordance with sections 77 and 78 of the Copyright, Designs and Patents Act 1988.

All rights reserved. No part of this book may be reprinted or reproduced or utilised in any form or by any electronic, mechanical, or other means, now known or hereafter invented, including photocopying and recording, or in any information storage or retrieval system, without permission in writing from the publishers.

Trademark notice: Product or corporate names may be trademarks or registered trademarks, and are used only for identification and explanation without intent to infringe.

British Library Cataloguing-in-Publication Data

A catalogue record for this book is available from the British Library

Library of Congress Cataloging-in-Publication Data

Names: Kaye, Bruce Norman, 1939- author.

Title: The rise and fall of the English Christendom : theocracy, Christology, order and power / Bruce Kaye.

Description: New York : Routledge, 2017. I Series: Routledge contemporary ecclesiology I Includes bibliographical references and index.

Identifiers: LCCN 2017035022 | ISBN 9781138305786 (hardback : alk. paper) I ISBN 9781315141596 (ebook)

Subjects: LCSH: Anglican Communion-History. I Church history.

Classification: LCC BX5005 .K43 2017 I DDC 283-dc23

LC record available at https://lccn.loc.gov/2017035022

ISBN: 978-1-138-30578-6 (hbk)

ISBN: 978-1-315-14159-6 (ebk)

Typeset in Sabon

by Apex CoVantage, LLC 


\section{Contents}

Preface vii

$\begin{array}{lr}\text { Introduction } & 1\end{array}$

\section{PART I}

Beginnings $\quad 5$

1 Theocracy and christendom $\quad 7$

2 Bede and the beginnings of the English Christendom 31

\section{PART II}

The Anglo-Norman Christendom

3 William I and Lanfranc 53

4 Anselm: obedience and distinction $\quad 77$

5 Establishing royal governance and the Becket challenge 105

6 Papal triumph and lay power $\quad 135$

\section{PART III}

The Tudor Royal Supremacy 165

7 Gardiner and the Hooker turning point 167

\section{PART IV}

The dying of the English Christendom

8 Sudden death: America and William White 197

9 Demise by attrition: Australia and William Grant Broughton 233 
vi Contents

PART V

Responding to the end of christendom

10 Theocracy, christology, order and power

Bibliography

301

Index 


\section{Preface}

This book is concerned with the way christians understand how they can be members of a kingdom that is not of this world and also members of a continuing community that most certainly is of this world. The first christian communities had to face the passing of generations and thus the handing on of their faith to the next generation. Thus began a process of tradition and that in time inevitably meant institutions of one kind or another. Power is exercised in all communities, but the coming of institutions in these new communities brought with it multiplied opportunities for the use and abuse of such power.

I have tried to look at this issue through the window of one of the longest living and ubiquitous forms of this strange 'two world' living - a christendom. That is to say, a realm which professes christian faith and shares power with lay and clerical members of that community. The particular christendom I am looking at is the one that grew up in England, its rise and fall and what we might learn from that story.

The book has had a long and in some ways difficult gestation. It attempts to engage with questions that in various forms I have had to confront in all my employment responsibilities. As a curate in a semi rural parish in Australia, my rector asked me to work with the northern half of the parish (there were seven church centres in the parish) to direct my attention to those who did not come to church and generally not to invite them to do so. How could I engage with people outside the institutional church that was supposed to be the custodian of the gospel? On appointment as Senior Tutor in a university college in England I was asked by the Principal to figure out a vision for that part of the college devoted to university students generally so that it was not just an appendage of the ordination training operation that was the other part of the college. How could an institution be the bearer of a vision and how did that relate to the academic vocation of being a university college in a British University.

Back in Australia on appointment as the Master of an Anglican university college in a secular university, I was asked to develop a vision for the college that was faithful to its Anglican foundation and had some relevant integrity in the university. In my last employment as General Secretary of 
the Anglican Church of Australia I was asked to contribute to the formation of policy and the development of a workable identity for the national church institutions in a stridently federal church constitution. All of these jobs forced me to think about how ideals direct actions and also about the nature of institutions in sustaining values and actions.

Furthermore, it has seemed to me that the more we can find some ultimate justification for our actions the greater the potential for us to do bad things. Academics can persuade themselves to do bad things in the name of the truth, just as church people can persuade themselves to do reprehensible things in the name of the gospel. Of course in both examples great and wonderful things can be generated by the pursuit of truth and commitment to the gospel, but it is not always necessarily so.

This puzzle of how ideals so partially effect actions was first raised for me as an undergraduate by the agnostic professor of Philosophy at the University of Sydney, John Anderson. His exegetical lectures on Plato's dialogues confronted the issue each week. Is life always to be lived in the cave with only shadows of the light outside to give any indication of a wider reality? My more focused attention to the nature of institutions was first galvanised fifty years ago by a conversation with Charles Vereker, which started on Durham station and ended as we parted at London Kings Cross. These two men started me on a lifelong curiosity about the nature of human society and the place of institutions.

I am grateful for many people who have helped advance my engagement with these questions over the years. To Donald Robinson who gave me a reading course on eschatology in the New Testament when I told him I did not want to follow the college curriculum. To my Doctor Vater in Basel, Bo Reicke, whose intense scholarship was blended with a generous and courteous nature. I learned from him the moral quality of scholarly activity and the kind of power it conveys when joined to a model of humility. C. K. Barrett was a kindly and generous mentor in difficult times. Kingsley reminded me of what I had learned as an undergraduate from the Roman historian, Edwin Judge, to pay careful attention to texts.

In terms of my employment experience, John Cockerton who, in surprising circumstances, gave me such a generous brief for the shaping of an institution in Durham. To Keith Rayner, Primate of the Anglican Church of Australia, who similarly offered me a challenge too good to pass by and accompanied it with wholehearted support and a wise and godly example.

Over the years these people, amongst many others, have contributed to the thinking that lies behind this book. Many colleagues in universities and churches around the world whom I have met through my various employments constitute that community. I particularly wish to thank Christopher Haigh, who not only read the draft of the complete manuscript he also persuaded me to include the chapter on Gardiner and Hooker. Long-term conversationalists Hugh MacKay and Keith Mason whose professional skills are in different areas from mine. Stanley Hauerwas, a long-time friend, always 
challenging, provocative and supportive, Stephen Pickard relentlessly imaginative and a constant friend, John Gascoigne, who lent me his rich historical knowledge, Ian Douglas a valiant pilgrim in the life of the Episcopal Church and others who have helped me on the way, sometimes not knowing they did so. In a slightly different category, the members of the Heretics Club in Sydney who heard parts of earlier forms of this book, the members of my house group at St Michaels Anglican Church Vaucluse, and then David Ragg, Brian Selley and John Black, who have been fellow campaigners in a regular weekly exercise of a different kind of intellectual discipline.

My thanks go to the many libraries and staff including at Moore College in Sydney; University Libraries at Charles Sturt, New South Wales, Adelaide, the Australian National University, Cambridge (UK), Duke (Durham NC) and Seattle. The State Library of New South Wales, the British Library and the National Library of Australia have been mines of information and help. The vast array of online archives, journals and books have transformed the work of scholarship.

My best thanks go to my wife Louise whose love and commitment lighten every day of my life and who also read a lot of the material in this book and listened to innumerable rambles on the latest discovery. 


\section{Introduction}

In the second half of the twentieth century one might have thought that religion had finally been removed from the pubic square and that modern societies were ultimately secular with religion relegated to the private domain. Of course, this was never really the situation but it was a widely held perception. In the first quarter of the twenty-first century that perception has been if not shattered, at least seriously dinted as religion has made a dramatic return to the public square especially in the context of political disturbance and violence. This return has prompted a significant re-think within the three largest religious traditions of Judaism, Christianity and Islam, as they try to come to terms with violence within their own households. The other side of this for citizens and nations is how religion fits in the public polity of modern states, especially those that have grown out of or been influenced by the European experience. These challenges are more pointed for christians whose religion has played a significant role in the emergence of modern societies with European heritages. The role of the English in this process has been both remarkable and distinctive. It is in this context that The Rise and Fall of the English Christendom: Theocracy, Christology, Order and Power has been written.

These questions have regularly been thought of in terms of the very modern concepts of 'church' and 'state'. There is however a longer tradition of the relationship between Christianity and a polity. That pattern, from which Western modernity emerged, was a christendom. This book sets out to examine a critical part of the christendom that developed in England as a way of approaching some of the issues facing the churches left over from that christendom. I am more concerned to suggest a way of approaching current issues than offering solutions to particular problems.

The term Christendom is widely used to mean merely the extent of Christian belief amongst populations around the world. For example Philip Jenkins in his very influential book The Next Christendom uses the term to describe an area where Christian belief and practice have come to be important parts of the social fabric. ${ }^{1}$ Judith Herrin in her book The Formation of

1 Philip Jenkins, The Next Christendom, 2002 


\section{Introduction}

Christendom sets out her ambition in more reflexive terms. 'I have asked how Christianity developed a dominant position and status in Europe, of which the term Christendom could justifiably be used.'2 In the late medieval period the growth in power and influence of the papacy across nations in Europe also provided a different idea of a christendom that was ecclesiastically governed or led from Rome. Vitally important as this movement was, it did not represent a territorial rule and was not a nation.

In the history of Christianity the term is notoriously used for the political establishment initiated by Constantine in the Roman Empire. This Christendom was primarily a political entity. Later christendoms of Western Europe emerged out of the empire of Charlemagne and the Holy Roman Empire and there were also those 'micro christendoms' which Peter Brown identified. ${ }^{3}$ Given the traditional historiography of Christianity in Western Europe, it is easy to forget that in early Christianity there were churches to the east that spread as far as China. Indeed Western European Christianity was but one part of a vast large canvas that stretched to eastern edge of the map of the known world. ${ }^{4}$

This book operates within two major frameworks. First of all, there is the work of Peter Brown. It is evident from the extensive and ground-breaking work of Peter Brown that it is necessary to speak of a number of christendoms in the history of Western Christianity. Each of these christendoms has its own history and characteristics. Brown argued that the rise of the Carolingian empire engulfed much of continental Europe including these micro christendoms into a 'kingdom of truly "imperial" dimensions.' On the basis of this Frankish domination emerged a new form of christendom that they regarded as 'the only true "Christendom" that mattered.' Brown says that this happened because "few rivals to the Frankish definition of Christendom had survived the political storms of the seventh century. ${ }^{5}$ The English Christendom was one of the micro christendoms that survived and one aspect of its story is the continuing untidy relation between the successors of the christendom of the Carolingian version.

The focus of this book is that particular christendom that emerged amongst the English off the northwestern edge of continental Europe. These micro christendoms were polities that professed christianity and managed with institutional arrangements to fulfil that vocation. The phenomenon of such christendoms has to do primarily with the interplay between the instruments of governance and the authority and power they represent in the practices of this christian community. My working definition is that these sorts of christendoms are political units which profess to be a christian

2 Judith Herrin, Formation of Christendom, 1989 p. 8

3 See Peter Brown, Western Christendom, 2013 especially Chapter 16

4 See Peter Brown, Western Christendom, 2013 especially pp. xvi-ff; Philip Jenkins, Next Christendom, 2002 and Philip Jenkins, Lost History, 2008

5 Peter Brown, Western Christendom, 2013 p. 378 
polity and in which there is a coalescence of power and authority between the lay and clerical elements.

The second framework is the enduring problem in Christianity of the presence of God in the mundane or empirical circumstance in which christians are called to live out the terms of their christian vocation. The experience of theocracy in ancient Israel provides not only a precedent for these challenges and difficulties but also points to some of the issues that confronted the early christians in their different circumstances and their very different understanding of the Kingdom of God. Despite these differences, issues of continuity and thus institutionalisation were very similar. In both there came to be openings for differences and levels of responsibility and authority that could so easily be turned into differences of power and control. The challenge not to forget the underlying purposes for which responsibility was given and the practice of the essential christian values that was required for all inhabitants of these ecclesial institutions. The early christians faced some very particular challenges in trying to make their way in a world that did not constitute their real citizenship, in which they travelled as pilgrims and aliens marching to the beat of the kingdom of Jesus that he told Pilate was not of this world.

In this context I have four particular interests in this book. I would like to try to elucidate some of the issues of christendom as a theocracy and as an example of divine presence in Christianity. Second, I wish to underline the long continuity of the English Christendom and thus of the story that is the inheritance of English churches, especially Anglicanism. I write this in some critical distance from the idea that Anglicanism began in the sixteenth century with the Tudor reformation. The more I have studied the earlier period represented in this book the more that idea seems to me to be seriously inadequate. Third, I am interested in opening up some of the lineaments of how the past and its living presence works for a tradition of faith like English Christianity and its progeny. Fourth, I want to illustrate with two examples some of the problems that radical social and institutional change brings for any recognisable continuity of faith. The American War of Independence killed quite suddenly and dramatically the institutional connections with the English Christendom. The new Republic established a radically different social and political environment for the continuing Episcopalians. The convict colony of New South Wales was established as an arm of the English Christendom and change came slowly by gradual attrition and not by violent eruption. The new polity came in different ways to the different self-governed colonies, which were scattered around the coastline of a vast continent. As a result many of the local colonial sentiments remained and they never achieved the kind of national sentiment that occurred in the United States. A national church constitution did not come until the twentieth century. The differences between these two examples produced churches that were different both constitutionally and culturally. 
With these interests in mind the book proceeds with an opening chapter concerned to elaborate something of the relation between theocracy and christendom followed by an introductory chapter for the English Christendom focussing on the presentation of the widely influential Bede. There follow four chapters on the crucial and formative period of the Anglo-Norman Christendom in which vital foundations were laid for the future pattern of the English Christendom. This one-hundred and fifty-year period from the Norman Conquest to the Magna Carta provided the shape and structure of the future of the English Christendom and illustrates key elements. William I and Lanfranc secured the consolidation of a national church and polity in which the king was supreme. This pattern of lay sovereignty over the christendom persisted throughout the period up until the dramatic constitutional changes of the sixteenth century initiated by Henry VIII. The complete rule of the king was challenged by the investiture contest. Concession was made to Anselm on investiture but sovereignty survived by other means. The sovereignty was carefully ordered by the reforms of Henry II only to be challenged by Becket's demand for a jurisdictional separation for church courts for clergy. This was the most serious challenge to the Anglo-Norman pattern, but it survived by a somewhat messy compromise to rule another day. The same more or less could be said of John's relations with Innocent III though in this case there were more severe signs of future internal challenges in the kingdom with the rise of the powers of the barons and the creation of the Magna Carta.

Later the rise of the Tudors and the assertion of a comprehensive Royal Supremacy by Henry VIII that overpowered the traditional form of the English Christendom proved to be a significant turning point for christendom and its rationale. Early in this period Stephen Gardiner argued out of the past for the absolute character of royal power at the head of a hierarchy. Richard Hooker towards the end of the reign of Elizabeth I argued on more fundamental theological grounds so that he opened a way into the future.

These chapters are followed by a detailed discussion of the two examples of adjustment in the United States and New South Wales. A final chapter draws some conclusions with particular focus on institutions and power. 


\section{References}

Act of Supremacy 1534, 1534, 26 Henry VIII, c.1., United Kingdom, http://www.constitution.org/sech/sech_074.htm

Act of Supremacy, 1559, Statutes of the Realm, IV, 350 f.: I Elizabeth, c. I, United Kingdom, http://www.constitution.org/sech/sech_081.txt

Adams, John, et al., Papers of John Adams (Cambridge, Mass.: Belknap Press of Harvard University Press, The Adams Papers: Series III, General Correspondence and Other Papers of the Adams Statesmen, 1977)

Anderson, Benedict, Imagined Communities: Reflections on the Origin and Spread of Nationalism (London; New York: Verso, Revised, 2006)

Anglican Consultative Council and Inter-Anglican Theological and Doctrinal Commission, For the Sake of the Kingdom: God's Church and the New Creation (Cincinnati, Ohio: Published for the Anglican Consultative Council by Forward Movement Publications, North American, 1986) The Anglo-Saxon Chronicle Part 7: A. D. 1102-1154, The Online Medieval \& Classical Library Series Editor D. B. Killings http://omacl.org/Anglo/part7.html. Tr. James Ingram Anselm and Walter Fröhlich, The Letters of Saint Anselm of Canterbury (Kalamazoo, Mich.: Cistercian Publications, 1990)

Armstrong, Dorsey , 'Holy Queens as Agents of Christianization in Bede's "Ecclesiastical History": A Reconsideration', Medieval Encounters 4.3 (1998), (228-241)

Atkinson, Alan , 'Time, Place and Paternalism: Early Conservative Thinking in New South Wales', Australian Historical Studies 23.90 (1988), (1-18)

Austin, Albert G. , Australian Education 1788-1900: Church, State and Public Education in Colonial Australia (Melbourne: Pitman, 1961)

Austin, Albert G. , Select Documents in Australian Education, 1788-1900 (Carlton, Vic.: Pitman Pacific Books, 1972)

Avis, Paul D. L. , 'Richard Hooker and John Calvin', Journal of Ecclesiastical History 32 (1981), (19-28)

Baldwin, Alison M. , The New England Clergy and the American Revolution (New York:

Frederick Ungar, First edition 1928, 1958)

Baldwin, John W. , 'Master Stephen Langton, Future Archbishop of Canterbury: The Paris

Schools and Magna Carter', English Historical Review 123.503 (2008), (811-846)

Bardesanes and H. J. W. Drijvers, The Book of the Laws of Countries; Dialogue on Fate of

Bardaișan of Edessa (Assen: Van Gorcum, Semitic Texts with Translations, 1965)

Barlow, Frank, The English Church, 1066-1154: A History of the Anglo-Norman Church

(London; New York: Longman, 1979)

Barlow, Frank, Thomas Becket (London: Orion, 1997)

Barlow, Frank, 'View of Archbishop Lanfranc', Journal of Ecclesiastical History 16.2 (1965), (163-177)

Barratt, Nick , 'Finance and the Economy in the Reign of Henry II', in Christopher Harper-Bill and Nicholas Vincent (eds.), Henry II: New Interpretations, pp. 242-256 (Woodbridge, UK; Rochester, NY: Boydell Press, 2007)

Bartlett, Robert , England Under the Norman and Angevin Kings, 1075-1225 (Oxford: Clarendon Press, 2000)

Bauckham, Richard , 'Hooker, Travers and the Church of Rome in the 1580s', Journal of Ecclesiastical History 29.1 (1978), (37-50)

Bauckham, Richard , 'Richard Hooker and John Calvin: A Comment', The Journal of Ecclesiastical History 32 (1981), (29-33)

Beardsley, E. Edwards, Life and Correspondence of the Right Reverend Samuel Seabury, D. D., First Bishop of Connecticut, and of the Episcopal Church in the United States of America (Boston: Houghton, Mifflin and Co, 1881)

Becket, Thomas, and Anne Duggan, The Correspondence of Thomas Becket, Archbishop of Canterbury, 1162-1170 (Oxford; New York: Clarendon Press; Oxford University Press, Oxford Medieval Texts, 2000)

Bede, R. E. Latham, and Leo Sherley-Price, A History of the English Church and People (Harmondsworth: Penguin, Revised, Penguin Classics, 1968)

Bentham, Jeremy, A Plea for the Constitution Shewing the Enormities Committed to the Oppression of British Subjects, Innocent as well as Guilty ... in and by ... the Penal Colony of 
New South Wales: Including an Inquiry into the Right of the Crown to Legislate Without

Parliament in Trinidad, and Other British colonies (London City: Mawman and Hatchard, 1803)

Berger, Peter L. , The Sacred Canopy: Elements of a Sociological Theory of Religion (Garden

City, NY: Doubleday, 1st edition, 1967)

Best, Geoffrey , Temporal Pillars: Queen Anne's Bounty, the Ecclesiastical Commissioners, and the Church of England (Cambridge: Cambridge University Press, 1964)

Biancalana, Joseph , 'For Want of Justice: Legal Reforms of Henry II', Columbia Law Review 88.3 (1988), (433-536)

Blumenthal, Uta-Renate, The Investiture Controversy: Church and Monarchy from the Ninth to the Twelfth Century (Philadelphia: University of Pennsylvania Press, Middle Ages Series, 1988) Blumenthal, Uta-Renate , Anders Winroth and Peter Landau (Eds.), Canon Law, Religion and Politics: Liber Amicorum Somerville (Washington, DC: Catholic University of America Press, 2012)

Booth, Paul A. , 'King Alfred versus Beowulf: The Re-Education of the Anglo-Saxon Aristocracy', Bulletin of the John Rylands Library 79 (1997), (41-66)

Border, Ross , Church and State in Australia 1788-1872: A Constitutional Study of the Church of England in Australia (London: SPCK, 1962)

Border , Ross , 'Thomas Hobbes (1783-1860)', Australian Dictionary of Biography (1967) Brand, Paul, 'Henry II and the Creation of English Common Law', in Christopher Harper-Bill and Nicholas Vincent (eds.), Henry II: New Interpretations, pp. 215-241 (Woodbridge, UK; Rochester, NY: Boydell Press, 2007)

Bray, Gerald (Ed.), Documents of the English Reformation (Cambridge: James Clarke \& Co, 2004)

Brett, M. , The English Church Under Henry I (London: Oxford University Press, 1975)

Bridenbaugh, Carl, Mitre and Sceptre; Transatlantic Faiths, Ideas, Personalities, and Politics, 1689-1775 (New York: Oxford University Press, 1962)

Brooke, Christopher N. L. , 'Gregorian Reform in Action: Clerical Marriage in England 1050-1200', Cambridge Historical Journal 12 (1956), (1-21)

Brooke, Zachary N. , 'The Effect of Becket's Murder on Papal Authority in England', Cambridge Historical Journal 2 (1928), (213-228)

Brooke, Zachary N. , The English Church \& the Papacy: From the Conquest to the Reign of John (Cambridge: Cambridge University Press, 1989)

Brooke, Zachary N. , 'Pope Gregory VII's Demand for Fealty from William the Conqueror', The English Historical Review 26.102 (1911), (225-238)

Broughton, William G. , Charge to the Clergy of the Archdeaconry of New South Wales, at the Primary Visitation (Sydney: 1830)

Broughton, William G. , Correspondence of William Grant Broughton to Edward Coleridge 1836-1852, Letter Book held in Moore College Library Sydney, Currently being transcribed and edited for digital publication by B. N. Kaye

Broughton, William G. , The Counsel and Pleasure of God in the Vicissitudes of States and Communities (Sydney: Mansfield, 1829)

Broughton, William G. , Diary Kept During the Voyage of the Ship John from England to New South Wales,Correspondence and Diary of William Grant Broughton, State Library of New South Wales, 1829

Broughton, William G. , Reply of the Lord Bishop of Australia to the Reverend the Clergy and the Missionaries, in Connexion with the Church Missionary Society in New Zealand (1839) Church Missionary Society, MS CN/03. On microfilm, National Library of Australia

Broughton, William G. , Sermons on the Church of England: Its Constitution, Mission, and Trials (London: Bell and Daldy, B. Harrison, 1857)

Broughton, William G. , Speech of the Lord Bishop of Australia in the Legislative Council upon the Resolution for Establishing a System of General Education (Sydney: James Tegg, 1839)

Brown, Peter , The Rise of Western Christendom: Triumph and Diversity, A.D. 200-1000

(Malden, Mass.: Wiley-Blackwell, 10th anniversary revised, The Making of Europe, 2013)

Brydon, Michael , The Evolving Reputation of Richard Hooker: An Examination of Responses, 1600-1714 (Oxford: Oxford University Press, 2006)

Buber, Martin , Kingship of God (London: Allen and Unwin, 3rd, newly enlarged edition, 1967) Bursell, Rupert , 'The Clerical Oath of Allegiance', Ecclesiastical Law Journal 17 (2015),

(295-305) 
Bury, John B. , The Cambridge Medieval History: Vol 6 (Cambridge: Cambridge University

Press, 1929)

Butlin, Noel G. , Forming a Colonial Economy, Australia 1810-1850 (Cambridge; Melbourne:

Cambridge University Press, 1994)

Campenhausen, $\mathrm{H}$. von, Ecclesiastical Authority and Spiritual Power in the Church of the First Three Centuries (Oxford: A and C Black, 1969)

Cantor, Norman F. , Church, Kingship, and Lay Investiture in England, 1089-1135 (New York: Octagon Books, Princeton Studies in History, Vol. 10, 1969)

Carpenter, David A. , 'Archbishop Langton and Magna Carta: His Contribution, His Doubts and His Hypocrisy', English Historical Review 126.522 (2011), (1041-1065)

Chavura, Stephen , ' “... but in Its Proper Place... . " Religion, Enlightenment, and Australia's Secular Heritage: The Case of Robert Lowe in Colonial NSW 1842-1850', Journal of Religious History 38.3 (2014), (356-376)

Cheney, Christopher R. , 'England and the Roman Curia Under Innocent III', Journal of Ecclesiastical History 18.2 (1967), (173-186)

Cheney, Christopher R. , Pope Innocent III and England (Stuttgart: Hiersemann, 1976)

Cheney, Mary, 'The Compromise of Avranches of 1172 and the Spread of Canon Law in

England', The English Historical Review 56.222 (1941), (177-197)

Chiwanga, Simon, 'Beyond the Monarch/Chief: Reconsidering Episcopacy in Africa', in Ian T. Douglas and Kwok Pui-lan (eds.), Beyond Colonial Anglicanism: The Anglican Communion in the Twenty-first Century, pp. 297-317 (New York: Church Publishing Inc., 2001)

Churton, Edward, and Joshua Watson, Memoir of J. Watson (Oxford: Oxford University Press, 1861)

Clark, C. M. Hope , A History of Australia (Carlton, Vic.: Melbourne University Press, 1962-1987)

Clark, J. C. Douglas , English Society, 1660-1832: Religion, Ideology and Politics During the Ancien Regime (Cambridge: Cambridge University Press, 2nd edition, 2000)

Clark, J. C. Douglas, Revolution and Rebellion: State and Society in England in the

Seventeenth and Eighteenth Centuries (Cambridge: Cambridge University Press, 1986)

Clarke, Henry Lowther, Constitutional Church Government in the Dominions Beyond the Seas and in Other Parts of the Anglican Communion (S.P.C.K., 1924)

Coates, Simon, 'The Bishop as Pastor and Solitary: Bede and the Spiritual Authority of the Monk-Bishop', Journal of Ecclesiastical History 47.4 (1996), (601-619)

Collinson, Patrick, 'Hooker and the Elizabethan Establishment', in A. S. McGrade (ed.), Richard Hooker and the Construction of Christian Community, pp. 149-181 (Tempe, Arizona: Arizona

Board of Regents for Arizona State University, 1997)

Commission Great Britain, Record and Benjamin Thorpe, Ancient Laws and Institutes of England, Comprising Laws Enacted Under the Anglo-Saxon Kings from Æthelbirht to Cnut, with an English Translation of the Saxon; the Laws Called Edward the Confessor's; the Laws of William the Conqueror, and Those Ascribed to Henry I: Also, Monumenta ecclesiastica Anglicana, from the Seventh to the Tenth Century; and the Ancient Latin Version of the AngloSaxon Laws: With a Compendious Glossary, etc. [Edited by Benjamin Thorpe .], pp. X, 548 (London: 1840)

Commonwealth of Australia, Australian Constitution, (2012)

http://www.aph.gov.au/About_Parliament/Senate/Powers_practice_n_procedures/Constitution. Accessed: 18 August 2017

Condren, Conal , 'The Creation of Richard Hooker's Public Authority: Rhetoric, Reputation and Reassessment', Journal of Religious History 21.1 (1997), (35-59)

Condren, Conal, The Status and Appraisal of Classic Texts: An Essay on Political Theory, Its Inheritance, and on the History of Ideas (Princeton, NJ: Princeton University Press, 1985)

Coombs, Herbert C. , The Fragile Pattern: Institutions and Man (Sydney: Australian

Broadcasting Commission, Boyer Lectures, 1970)

Cowdrey, Herbert E. J. , Lanfranc, the Papacy and the See of Canterbury (Roma: Herder

Editrice e Libreria, 1993)

Cowdrey, Herbert E. J. , Lanfranc: Scholar, Monk, and Archbishop (Oxford; New York: Oxford University Press, 2003)

Cowdrey, Herbert E. J. , Pope Gregory VII, 1073-1085. (Oxford; New York: Oxford University Press; Clarendon Press, 1998) 
Cusack, Pearse , 'Lanfranc Congress, Pavia', Downside Review 108 (1990), (66-76)

Davies, William D. , The Gospel and the Land: Early Christianity and Jewish Territorial Doctrine (Berkeley, Los Angeles, London: University of California Press, 1974)

d'Avray, David L. , 'Magna Carta: Its Background in Stephen Langton's Academic Biblical

Exegesis and Its Episcopal Reception', Studi Medievali 38 (1997), (426-438)

Daw, E. D. , 'Synodical Government for the Church of England in N.S.W. the First Attempt', Journal of Religious History 6.2 (1970), (151-176)

Dawson, Christopher , The Making of Europe: An Introduction to the History of European Unity (Sheed and Ward, 1932)

DeGregorio, Scott , 'Monasticism and Reform in Book IV of Bede's 'Ecclesiastical History of the English People", Journal of Ecclesiastical History 61.1 (2010), (673-687)

Demacopolous, George , 'Gregory the Great and the Pagan Shrines of Kent', Journal of Late Antiquity 1.2 (2008), (353-369)

'De Libertate Beccensis Monasterii', in Jean Mabillon (ed.), Annales Ordines Sancti Benedict, pp. 601-605 (Paris: 1745)

Delivré, Fabrise , 'The Foundations of Primatial Claims in the Western Church (Eleventh Thirteenth Centuries)', Journal of Ecclesiastical History 59.3 (2008), (383-406)

Dewey, Clive, The Passing of Barchester (London; Rio Grande, Ohio, U.S.A.: Hambledon

Press, 1991)

Dialogus de Scaccario (New York: Fordham University, 1179), bb,

www.fordham.edu/Halsall/source/excheq1.asp. Accessed: 18 August 2014

Dobschutz, Ernst von, George Bremner and William Douglas Morrison, Christian Life in the Primitive Church (London, New York: Williams and Norgate; G. P. Putnam's Sons, Theological Translation Library, 1904)

Douglas, David C. , English Historical Documents (New York: Oxford University Press, 1952-1969)

Douglas, D. C. 'A Charter of Enfeoffment under William the Conqueror', English Historical Review 42 (1927), (245-247)

Drake, Harold A. , Constantine and the Bishops: The Politics of Intolerance (Baltimore, MD: Johns Hopkins University Press, Ancient Society and History, 2000)

Duggan, Anne , 'Henry II, The English Church and the Papacy, 1154-76', in Christopher Harper-Bill and Nicholas Vincent (eds.), Henry II: New Interpretations, pp. (Woodbridge, UK; Rochester, NY: Boydell Press, 2007)

Duggan, Anne J. , 'Roman, Canon and Common Law in Twelfth-Century England: The Council of Northampton', Historical Research 83.221 (2010), (379-408)

Dunn, James D. G. , The Parting of the Ways (London: SCM Press, 1991)

Eadmer, Martin Rule and Great Britain Public Record Office, Eadmeri Historia Novorum in Anglia, et opuscula duo de vita Sancti Anselmi et quibusdam miraculis ejus (London: Longman, Rerum Britannicarum medii aevi scriptores, 1884)

Eadmer and Richard W. Southern, The Life of St. Anselm, Archbishop of Canterbury (London; New York: T. Nelson; Medieval Texts, 1962)

Elliot, Kenneth Ray , 'Anglican Church Policy, Eighteenth Century Conflict, and the American Episcopate', Ph.D., Mississippi State, 2007

Elliot, Michael D. , 'New Evidence for the Influence of Gallic Canon Law in Anglo-Saxon

England', Journal of Ecclesiastical History 64.4 (2013), (700-730)

Ely, Richard , Unto God and Caesar: Religious Issues in the Emerging Commonwealth, 1891-1906 (Clayton, Vic.: Melbourne University Press, Studies in Australian Federation, 1976) English Translation of Magna Carta (London City: British Library, 1215)

Eusebius and Geoffrey A. Williamson, The History of the Church from Christ to Constantine (Baltimore: Penguin Books, Penguin Classics; L138, 1965)

Finn, Paul D. , Law and Government in Colonial Australia (Melbourne: Oxford University Press, Law and Government, 1987)

Fitzneale, Richard, et al., Dialogus de Scaccario: The Dialogue of the Exchequer (Oxford:

Oxford University Press, 2007)

Fortescue, John, and Shelley Lockwood, Sir John Fortescue: On the Laws and Governance of England (New York: Cambridge University Press, Cambridge Texts in the History of Political

Thought, 1997) 
Fox, Robin Lane, Pagans and Christians (New York: Knopf, 1st American edition, 1987)

Fraher, Richard M. , 'The Becket Dispute and Two Decretist Traditions: The Bolognese Masters Revisited and Some New Anglo-Norman Texts', Journal of Medieval History 4.4 (2012), (347-368)

Frame, Thomas R. , Church and State: Australia's Imaginary Wall (Sydney: UNSW Press, 2006)

Furhmann, Horst , 'The Pseudo-Isidorian Forgeries', in Detlev Jasper and Horst Fuhrmann (eds.), Papal Letters in the Early Middle Ages, pp. 135-195 (Washington, DC: 2001)

Fuhrmann, Horst, and Detlev Jasper , Papal Letters in the Early Middle Ages (Washington, DC: Catholic University of America Press, 2001)

Gardiner, Stephen, and Pierre Janelle, Obedience in Church \& State; Three Political Tracts by Stephen Gardiner (Cambridge, England: Cambridge University Press, 1930)

Gellner, Ernest , Thought and Change (Weidenfeld and Nicolson, 1964 (1969))

Gibbs, Lee W. , 'Introduction Book l', in W. Speed Hill (ed.), Richard Hooker: Of the Lawes of Ecclesiastical Polity, pp. 1-80 (Binghampton: Centre for Medieval and Renaissance Studies, 1993)

Gibson, Margaret T. , Lanfranc of Bec (Oxford, England: Clarendon Press, 1978)

Gibson, Margaret T. , 'Lanfranc's Commentary on the Pauline Epistles', Journal of Theological Studies (1971), (86-112)

Gilchrist, John T. , 'Canon Law Aspects of the Eleventh Century Gregorian Reform Programme', Journal of Ecclesiastical History 13.1 (1962), (21-38)

Gladstone, William E. , The State in Its Relations with the Church (London: John Murray, 1838)

Gladwin, Michael , Anglican Clergy in Australia 1788-1850: Building a British World

(Woodbridge, UK: The Boydell Press, 2015)

Gladwin, Michael , 'Flogging Parsons? Australian Anglican Clergymen, the Magistry, and

Convicts', Journal of Religious History 36.3 (2012), (386-403)

Grandsen, Antonia , 'Bede's Reputation as an Historian in Medieval England', Journal of

Ecclesiastical History (1981), (397-425)

Green, David G. , and Lawrence G. Cromwell , Mutual Aid or Welfare State: Australia's Friendly

Societies (Sydney: George Allen \& Unwin, 1984)

Green, Judith A. , 'Unity and Disunity in the Anglo-Norman State', Historical Research 63.148

(1989), (115-134)

Grislis, Egil , 'The Role of Consensus in Richard Hooker's Theological Enquiry', in Robert E.

Cushman and Egil Grislis (eds.), The Heritage of Christian Thought: Essays in Honor of Robert Lowry Calhoun, pp. 64-88 (New York: Harper and Row, 1965)

Grose, Kelvin , '1847: The Educational Compromise of the Lord Bishop of Australia', Journal of Religious History 2 (1961), (233-248)

Guy, John A. , 'Thomas More and Christopher St German: The Battle of the Books', Moreana 21.83-84 (1984), (5-25)

Haigh, Christopher , English Reformations: Religion, Politics, and Society Under the Tudors (Oxford: Oxford University Press, 1993)

Harnack, Adolf von, and J. R. Wilkinson, Bible Reading in the Early Church (New York; London: G.P. Putnam; Williams \& Norgate, Crown Theological Library, 1912)

Harper-Bill, Christopher , 'John and the Church of Rome', in S. Church (ed.), King John: New Interpretations, pp. 289-315 (Woodbridge, Suffolk: The Boydell Press, 1999)

Harris, Margaret A. , 'Lanfranc and St Anselm', in D. Farmer (ed.), Benedict's Disciples, pp. 154-175 (Leonminster: Gracewing, 1980)

Hastings, Adrian , The Construction of Nationhood: Ethnicity, Religion and Nationalism (Cambridge: Cambridge University Press, 1997)

Hatch, Edwin , The Organization of the Early Christian Churches (London: Longmans Green, 1892)

Hauerwas, Stanley, After Christendom?: How the Church Is to Behave if Freedom, Justice, and a Christian Nation Are Bad Ideas (Nashville: Abingdon Press, 1999)

Hauerwas, Stanley, John Berkman and Michael G. Cartwright, The Hauerwas Reader (Durham, NC: Duke University Press, 2001)

Hayward, Paul-Antony , 'Gregory the Great as "Apostle of the English" in Post-conquest

Canterbury', Journal of Ecclesiastical History 55.1 (2004), (19-57) 
Healy, Patrick , 'A Supposed Letter of Archbishop Lanfranc: Concepts of the Universal Church in the Investiture Contest', The English Historical Review 121.494 (2006), (1385-1407)

Heclo, Hugh, On Thinking Institutionally (Boulder, Colo.: Paradigm Publishers, On Politics, 2008)

Hegedus, Tim , 'Necessity and Free Will in the Thought of Bardaisan of Edessa', Laval théologique et philosophique 59.2 (2003), (333-344)

Herrin, Judith, The Formation of Christendom (Princeton, NJ: Princeton University Press, 1st Princeton paperback print, with revisions and ill., Princeton Paperbacks, 1989)

Higham, Nicholas J. , (Re-) Reading Bede: The Ecclesiastical History in Context (London: Routledge, 2006)

Hirst, John B. , The Strange Birth of Colonial Democracy: New South Wales 1848-84 (Sydney:

Allen and Unwin, 1988)

Hoadly, Benjamin , The Nature of the Kingdom, or Church of Christ: A Sermon Preached Before the King ... on Sunday, March 31, 1717 (Glasgow: Printed for J. Gillies, The 13th edition, 1783)

Hoadly, Benjamin , and William Gibson, The Original and Institution of Civil Government,

Discuss'd (New York, NY: AMS Press, New, AMS Series in the Eighteenth Century, 2007)

Holmes, David L. , 'The Episcopal Church and the American Revolution', Historical Magazine of the Protestant Episcopal Church 47.3 (1978), (261-291)

Holmes, David L. , 'The Making of the Bishop of Pennsylvania, 1826-1827: Part I: Nestor's Finest Hour', Historical Magazine of the Protestant Episcopal Church 41.3 (1972), (225-262) Holopainen, Toivo J. , 'Anselm's "Argumentum" and the Early Medieval Theory of Argument', Vivarium 45 (2007), (1-29)

Holt, James C. , The Northerners: A Study in the Reign of King John (Oxford: Clarendon, 1992) Hooker, Richard, and Arthur Stephen McGrade, Richard Hooker, of the Laws of Ecclesiastical Polity: A Critical Edition with Modern Spelling (Oxford: Oxford University Press, 2013)

Hooker, Richard, and W. Speed Hill, The Folger Library Edition of the Works of Richard Hooker (Cambridge: Belknap Press of Harvard University Press, 1977)

Howe, Nicholas , 'Rome: Capitol of Anglo-Saxon England', Journal of Medieval and Early Modern Studies 34.1 (2004), (147-172)

Humphrey, Edward Frank, Nationalism and Religion in America, 1774-1789 (New York:

Russell \& Russell, 1965)

Hutchinson, Thomas, Strictures upon the Declaration of the Congress at Philadelphia; in a Letter to a Noble Lord, \& c (London: 1776)

Innocent III, Between God and Man: Six Sermons on the Priestly Office (Washington: The Catholic University of America Press, Medieval Texts in Translation, 2004)

Innocent, C. R. Cheney and W. H. Semple, Selected Letters of Pope Innocent III Concerning England (1198-1216) (London: Nelson, Medieval Texts, 1953)

Inter Anglican Theological and Doctrinal Commission, Communion, Conflict and Hope (London: The Anglican Communion Office, 2008)

Isidore of Seville and Stephen A. Barney, The Etymologies of Isidore of Seville (Cambridge: Cambridge University Press, 2006)

Jenkins, Philip , The Lost History of Christianity: The Thousand-Year Golden Age of the Church in the Middle East, Africa, and Asia- and How It Died (New York: HarperOne, 1st edition, 2008) Jenkins, Philip , The Next Christendom: The Rise of Global Christianity (Oxford; New York: Oxford University Press, 2002)

John of Salisbury, Ronald E. Pepin and Pontifical Institute of Mediaeval Studies, Anselm \& Becket: Two Canterbury Saints' Lives (Toronto: Pontifical Institute of Mediaeval Studies, 2009) Jones, A. H. M. , 'Were Ancient Heresies National or Social Movements in Disguise', Journal of Theological Studies 10.2 (1959), (280-298)

Kant, Immanuel , Idea of a Universal History from a Cosmopolitan Point of View (The BobbsMerrill Co, 1784), www.marxists.org/reference/subject/ethics/kant/universal-history.htm.

Accessed: 23 August 2016

Kasemann, Ernst , 'Paul and Early Catholicism', in (ed.), New Testament Questions of Today, pp. 237-251 (London: SCM Press, 1969)

Kaye, Bruce N. , The Argument of Romans with Special Reference to Chapter 6 (Austin: Schola Press, 1979)

Kaye, Bruce N. , 'An Australian Definition of Religion', University of New South Wales Law Journal 14.2 (1991), (332-351) 
Kaye, Bruce N. , 'The Baggage of William Grant Broughton: The First Bishop of Australia as Hanoverien High Churchman', Pacifica 8 (1995), (291-314)

Kaye, Bruce N. , 'Broughton and the Demise of the Royal Supremacy', Journal of the Royal Australian Historical Society 81 (1995), (39-51)

Kaye, Bruce N. , Conflict and the Practice of Christian Faith: The Anglican Experiment (Omaha, NE: Cascade Books, 2009)

Kaye, Bruce N. , 'Eschatology and Ethics in 1 and 2 Thessalonians', Novum Testamentum 17 (1975), (47-57)

Kaye, Bruce N. , 'How Can We Speak of "Canonical Scripture" Today?', Journal of Anglican Studies 11.1 (2013), (1-14)

Kaye, Bruce N. , 'The Laity in Church Governance According to Bishop Broughton', Journal of Religious History 20.1 (1996), (78-92)

Kaye, Bruce N. , 'Lightfoot and Baur on Early Christianity', Novum Testamentum 26 (1984), (193-224)

Kaye, Bruce N. , 'The Role of Tradition in Church State Relations in Mid-Nineteenth Century NSW: The Cases of Bishops Broughton and Barker', in D. Dockrill and R. Tanner (eds.), Tradition and Traditions, pp. 224-242 (Prudnetia, Supplementary Number, 1994)

Kaye, Bruce N. , 'The Strange Birth of Anglican Synods in Australia and the 1850 Bishop's Conference', Journal of Religious History 27.2, (2003), (177-197)

Kaye, Bruce N. , 'Selwyn and the Australasian Conference of Bishops, 1850', in Andrew K. Davidson (ed.), A Controversial Churchman: Essays on George Selwyn, Bishop of New Zealand and Lichfield, and Sarah Selwyn, pp. 146-158 (Wellington, New Zealand: Bridget Williams Books, 2011)

Knowles, David , 'The Canterbury Election of 1205-6', English Historical Review 53 (1938), (211-220)

Knowles, David , Anne J. Duggan and Christopher N. L. Brooke, 'Henry Il's Supplement to the Constitutions of Clarendon', The English Historical Review 87.345 (1972), (757-771)

Koke, Andrew M. , 'Limitations of an Episcopal Empire: The Church of England in the British Atlantic, 1675-1761', Ph.D., Indiana University, 2013

Korten, David C. , When Corporations Rule the World (San Francisco, Calif.; Bloomfield, Conn.: Berrett-Koehler Publishers: Kumarian Press, 2nd edition, 2001)

Krieder, Alan , The Change of Conversion and the Origin of Christendom (Harrisburg, Pa.:

Trinity Press International, Christian mission and modern culture, 1999)

Kreider, Alan , The Origins of Christendom in the West (Edinburgh: T \& T Clark, 2001)

Kreider, Alan, The Patient Ferment of the Early Church: The Improbable Rise of Christianity in the Roman Empire (Grand Rapids, MI: Baker Academic, 2016)

Kriston, Rennie, and Jason Taliodoros, 'Why Study Medieval Canon Law?', History Compass 12.2 (2014), (133-149)

Lactantius , Life of Constantine, bb, gbgm-umc.org/umw/bible/milan.stm. Accessed: 22

February 2017

Lake, Kirsopp (Ed.), The Apostolic Fathers with an English Translation by Kirsopp Lake (Cambridge: Harvard University Press, 1965)

Lake, Peter , 'The "Anglican Moment"?" Richard Hooker and the Ideological Watershed of the 1590s', in Stephen Platten (ed.), Anglicanism and the Western Christian Tradition, pp. 90-121 (Norwich: Canterbury Press, 2003)

Lake, Peter , Anglicans and Puritans? Presbyterianism and English Conformist Thought from Whitgift to Hooker (London: Unwin Hyman, 1988)

Lanfranc, David Knowles and Christopher Brooke, The Monastic Constitutions of Lanfranc (New York: Oxford University Press, Revised edition, Oxford Medieval Texts, 2002)

Lanfranc, V. Helen Clover and Margaret T. Gibson, The Letters of Lanfranc, Archbishop of Canterbury (Oxford; New York: Clarendon Press; Oxford University Press, Oxford Medieval Texts, 1979)

Lapidge, Michael , 'The School of Theodore and Hadrian', Anglo-Saxon England 15 (1986), (41-72)

Larson, Atria A. , 'Early Stages of Gratian's "Decretum" and the Second Lateran Council: A Reconsideration', Bulletin of Medieval Canon Law 21 (2007), (21-56)

Lawrence, Clifford Hugh, The English Church and the Papacy in the Middle Ages: Edited by C. H. Lawrence, et al. (London: Burns \& Oates, 1965) 
Legislative Council of New South Wales, Journal of the Legislative Council of New South Wales, Session 1859-60 (Sydney. Thomas Richards, Government Printer, 1860)

Leithart, Peter J. , Defending Constantine: The Twilight of an Empire and the Dawn of Christendom (Downers Grove, III.: IVP Academic, 2010)

Littell, Franklin H. , From State Church to Pluralism: A Protestant Interpretation of Religion in American History (New Brunswick, NJ: AldineTransaction, 2007)

Loveland, Clara O. , The Critical Years: The Reconstitution of the Anglican Church in the United States of America: 1780-1789 (Greenwich, Conn.: Seabury Press, 1956)

Lucas, Stephen, The Stylistic Artistry of the Declaration of Independence (US National Archives , 1989, http://www.archives.gov/national-archives-experience/charters/declaration_style.html. Accessed 8 June 2015)

Lumb, R.D. , The Constitutions of the Australian States (Brisbane: University of Queensland Press, 2nd edition, 1965)

Macdonald, Allan J. , Lanfranc: A Study of His Life, Work \& Writing (London: Society for Promoting Christian Knowledge, 2nd edition, 1944)

MacMullen, Ramsay, Christianizing the Roman Empire (New Haven: Yale University Press, 1984)

Maitland, Frederic William , 'Canon Law in England (Continued)', The English Historical Review 11.44 (1896), (641-672)

Marshall, Paul Victor , One Catholic and Apostolic: Samuel Seabury and the Early Episcopal Church (New York: Church Publishing, 2004)

Mason, Emma , 'William Rufus: Myth and Reality', Journal of Medieval History 3 (1977), (1-20) Mayr-Harting, Henry , 'Hilary, Bishop of Chichester (1147-1169) and Henry II', The English Historical Review 78.307 (1963), (209-224)

McConnell, Samuel D. , History of the American Episcopal Church: From the Planting of the Colonies to the End of the Civil War (London: Sampson Low Marston Searle and Rivington, 1891)

Meaney, N. K. , 'The Church of England in the Paradise of Dissent: A Problem of Assimilation', Journal of Religious History 5 (1964), (137-157)

Melbourne, A. C. V. , and R. B. Joyce, Early Constitutional Development in Australia: New South Wales 1788-1856, Queensland 1859-1922 (with notes to 1963 by the editor) (St. Lucia: University of Queensland Press, 2nd edition, Guides to Australian History, 1963)

Menzies, Robert , Central Power in the Australian Commonwealth: An Examination of the Growth of Commonwealth Power in the Australian Federation (London: Cassell, 1967) Merk, Otto , Handeln aus Glauben die Motivierungen der Paulinischen Ethik (Marburg; Lahn: Elwert; Marburger Theologische Studien, 1968)

Mills, Frederick V. , Bishops by Ballot: An Eighteenth Century Ecclesiastical Revolution (New York: Oxford University Press, 1978)

Moorhead, John , 'Bede on the Papacy', Journal of Ecclesiastical History 60.2 (2009), (217-232)

Morris, Colin , 'William I and the Church Courts', The English Historical Review 82.124 (1967), (449-463)

Mulligan, Robert F. , 'Spontaneously Evolved Social Order versus Positive Legislation in English Constitutional History', Review of Austrian Economics 17.1 (2004), (41-65)

Murray, Gilbert, Five Stages of Greek Religion (New York; London: Columbia University Press; Oxford University Press, 1925)

Nikolajsen, Jeppe Bach, 'Beyond Sectarianism: The Missional Church in a Post-Christian Society', Missiology: An International Review 41.4 (2013), (462-475)

Nikolajsen, Jeppe Bach, The Distinctive Identity of the Church: A Constructive Study of the Post-Christendom Theologies of Lesslie Newbigin and John Howard Yoder (2015)

Nikolajsen, Jeppe Bach, 'Missional Church: A Historical and Theological Analysis of an Ecclesiological Tradition', International Review of Mission 102.2 (2013), (249-261)

Noble, Thomas F. X. , 'Carolingian Religion', Church History 84.2 (2015), (287-307)

Nockles, Peter Benedict , The Oxford Movement in Context: Anglican High Churchmanship, 1760-1857 (Cambridge: Cambridge University Press, 1994)

Novikoff, Alex J. , 'Anselm, Dialogue and the Rise of Scholastic Disputation', Speculum 86 (2011), (387-418) 
Nye, Russel B. , The Cultural Life of the New Nation, 1776-1830 (New York: Harper, The New American Nation Series, 1960)

O'Brien, Bruce R. , 'Forgers of Law and Their Readers: The Crafting of English Political Identities Between the Norman Conquest and the Magna Carta', PS: Political Science \& Politics 43.3 (2010), (467-473)

Parkes, Malcolm B. , The Scriptorium at Wearmouth Jarrow (Durham: Durham Cathedral, Jarrow Lecture, 1982)

Parsonson, G. S. , 'Marsden Samuel', Dictionary of New Zealand Biography: Te Ara - the Encyclopedia of New Zealand (2012)

Pennington, Kenneth , 'The Canonists and Pluralism in the Thirteenth Century', Speculum 51.1 (1976), (35-48)

Pennington, Kenneth, Roman Law at the Papal Curia in the Early Twelfth Century, bb, http://faculty.cua.edu/pennington/PenningtonRomanLawLateranll.htm. Accessed: 22 January 2016

Perry, C. , A Diary of a Conference (Anglican Diocese of Melbourne, 1850)

Perry, W. S. (Ed.), Journals of the General Conventions of the Protestant Episcopal Church, in the United States of America, 1785-1835 (Claremeont: The Claremont Manufacturing

Company, 1874)

Pfeffer, Jeffrey, Power in Organizations (Boston: Pitman, 1981)

Phelan, Owen Michael, The Formation of Christian Europe: The Carolingians, Baptism, and the imperium christianum (Oxford: Oxford University Press, 2014)

Pietersen, Lloyd, Reading the Bible After Christendom (Harrisonburg, Va.: Herald Press, 2012)

Pirenne, Henri , Mohammed and Charlemagne (London, England: Allen \& Unwin, 1939)

Pollard, Justin , Alfred the Great: The Man Who Made England (London: John Murray, 2005)

Pollock, Frederick, Frederic William Maitland and Stroud Francis Charles Milsom, The History of English Law Before the Time of Edward I. Vol 1-2 (Cambridge: Cambridge University Press, 2nd edition, 1968)

Powicke, F. M. , Stephen Langton (London: Merlin Press, Oxford University Ford Lectures, 1965)

Prichard, Robert W. , A History of the Episcopal Church (Harrisburg: Morehouse, 1991)

Prichard, Robert W. , 'The Nature of Salvation: Theological Consensus in the Episcopal Church, 1801-73', (1997)

Ramelli, I. L. E. , 'Origen, Bardaisan, and the Origin of Universal Salvation', The Harvard Theological Review 102.2 (2009), (135-168)

Ray, R. D. , 'Bede the Exegete as Historian', in G. Bonner (ed.), Famulus Christi, pp. (London: SPCK, 1976)

Rayner, Keith , 'The Home Base of the Missions of the Church of England 1830-50', Journal of Religious History 2 (1962), (29-48)

Rennie, Kriston R. , and Jason Taliadoros , 'Why Study Medieval Canon Law?', History Compass 12.2 (2014), (133-149)

Richardson, H. G. , and G. O. Sayles, The Governance of Mediaeval England: From the Conquest to Magna Carta (Edinburgh: Edinburgh University Press, Publications: History, Philosophy, 1963)

Ridyard, Susan J. , The Royal Saints of Anglo-Saxon England: A Study of West Saxon and East Anglian Cults (Cambridge: Cambridge University Press, 1988)

Robinson, I. S. , 'Church and Papacy', in J. H. Burns (ed.), The Cambridge History of Medieval Political Thought c.350-c.1450, pp. 252-305 (Cambridge: Cambridge University Press, 1988)

Robinson, I. S. , 'Reform and the Church, 1073-1122', in David Luscombe and Jonathan RileySmith (eds.), The New Cambridge Medieval History, pp. 268-334 (Cambridge: Cambridge University Press, 1995)

Robinson, J. A. , 'Lanfranc's Monastic Constitutions', JTS 10 (1909), (375-388)

Rolker, Christof , 'Ivo of Chartres', Bulleting of Medieval Canon Law 114 (2002-2003), (114-143)

Rubenstein, Jay , 'Liturgy Against History: The Competing Visions of Lanfranc and Eadmer of Canterbury', Speculum 74.2 (1999), (279-309)

Ruud, Marylou , 'Unworthy Servants”: The Rhetoric of Resignation at Canterbury, 1070-1170', Journal of Religious History 22.1 (1998), (1-13) 
Saint Bishop of Hippo Augustine, Henry Bettenson and David Knowles, Concerning the City of God Against the Pagans: A New Translation by Henry Bettenson : [Edited,] with an Introduction by David Knowles (Harmondsworth: Penguin Books, 1972)

Schaff, Philip , Eusebius Pamphilius (1819-1893) (Ed.) and Rev. Arthur Cushman McGiffert , Ph.D. (Translator), Eusebius Pamphilius: Church History, Life of Constantine (Grand Rapids: Christian Classics Ethereal Library, 1819-1893), www.ccel.org/ccel/schaff/npnf201.html Schaff, Philip , and Henry Wace , A Select Library of Nicene and Post-Nicene Fathers of the Christian Church: Second Series: Vol 1 Life of Constantine (New York: The Christian Literature Company; etc., 1890)

Schott, Jeremy M. , Christianity, Empire, and the Making of Religion in Late Antiquity (Philadelphia: University of Pennsylvania Press, Divinations, 2008)

Shaw, George P. , Patriarch and Patriot, William Grant Broughton 1788-1853 (Melbourne: Melbourne University Press, 1978)

Society for the Propagation of the Gospel, Annals of the Colonial Church: Diocese of New Zealand (London: SPCK, 1847)

Southern, Richard W. , 'Lanfranc of Bec and Berengar of Tours', in R. W. Hunt , W. A. Pantin and Richard W. Southern (eds.), Studies in Medieval History Presented to Frederick Maurice Powicke, pp. 27-48 (Oxford: Oxford University Press, 1948)

Southern, Richard W. , Saint Anselm and His Biographer: A Study of Monastic Life and Thought 1059-c.1130 (Cambridge: Cambridge University Press, 1963)

Southern, Richard W. , 'Sally Vaughn's Anselm: An Examination of the Foundations', Albion: A Quarterly Journal Concerned with British Studies 20.2 (1988), (181-204)

Speed, Diane , 'Bede's Creation of a Nation in His "Ecclesiastical History" ', Parergon 10.2 (1992), (139-154)

Speed, Diane , 'Bede's Mapping of England', in G. Barnes (ed.), Travel and Travellers from Bede to Dampier, pp. 9-22 (Newcastle-upon-Tyne: Cambridge Scholars Press, 2005)

St German , Christopher , The Doctor and Student (Lonang Institute, 1518)

Stark, Rodney , The Rise of Christianity: A Sociologist Reconsiders History (San Francisco: HarperCollins, 1997)

Staunton, Michael , Thomas Becket and His Biographers (Woodbridge: Boydell Press, 2006) Stoneman, David , 'Richard Bourke: For the Honour of God and the Good of Man', Journal of Religious History 38.3 (2014), (341-355)

Stowe, Walter-Herbert , 'The Autobiography of Bishop William White', Historical Magazine of the Protestant Episcopal Church 22.4 (1953), (379-432)

Stowe, Walter-Herbert , The Life and Letters of Bishop William White (1937)

Strong, Rowan , Anglicanism and the British Empire c.1700-1850 (Oxford; New York: Oxford University Press, 2007)

Strong, Rowan , 'An Antipodean Establishment: Institutional Anglicanism in Australia, 1788c.1934 strong@socs.murdoch.edu.au', Journal of Anglican Studies 1.1 (2003), (61-90) Strong, Rowan , 'The Colonial Religion of the Anglican Clergy: Western Australia 1830 to c.1870', Journal of Religious History 38.1 (2014), (91-114)

Sumner, George , 'Why Anselm Still Matters', Anglican Theological Review 95.1 (2013), (25-35)

Sweeney, Eileen , 'The Rhetoric of Prayer and Argument in Anselm', Philosophy \& Rhetoric 38.4 (2005), (355-378)

The Sydney Morning Herald, Minutes of Proceedings of the Metropolitan and Suffragan Bishops of the Province of Australasia, held at Sydney, from October 1st to November 1st, AD, 1850, pp. 3, 4 (Sydney, 4 December)

Taliadoros, Jason, 'Law, Theology, and Morality: Conceptions of the Rights to Relief of the Poor in the Twelfth and Thirteenth Centuries', Journal of Religious History 37.4 (2013),

(474-493)

Tannehill, Robert C. , Dying and Rising with Christ: A Study in Pauline Theology (Berlin: Töpelmann, Beiheft zur Zeitschrift für die neutestamentliche Wissenschaft und die Kunde der Älteren Kirche, 1967)

Taylor, Charles , A Secular Age (Cambridge, Mass.: Belknap Press of Harvard University Press, 2007)

Temple, Sydney-Absalom , 'The Common Sense Theology of Bishop White', Ph.D., Columbia, 1947 
Thomas, Benjamin , 'Priests and Bishops in Bede's Ecclesiology: The Use of Sacerdos in the "Historia gentis Anglorum"', Ecclesiology 6.2010 (2010), (68-93)

Tierney, Brian , 'Some Recent Works on the Political Theories of the Medieval Canonists', Tradition 10 (1954), (594-625)

Truax, Jean , Archbishops Ralph d'Escures, William of Corbeil, and Theobald of Bec: Heirs of Anselm and Ancestors of Becket (Farnham, Surrey, England; Burlington, VT: Ashgate, 2012) Turner, Ralph V. , 'Richard Lionheart and English Episcopal Elections', Albion: A Quarterly Journal Concerned with British Studies 29.1 (1997), (1-13)

Vaughn, Sally N. , The Abbey of Bec and the Anglo-Norman State: 1034-1136 (Woodbridge: Boydell Press, 1981)

Vaughn, Sally N. , Anselm of Bec and Robert of Meulan: The Innocence of the Dove and the Wisdom of the Serpent (Berkeley: University of California Press, 1987)

Vaughn, Sally N. , Archbishop Anselm, 1093-1109: Bec Missionary, Canterbury Primate, Patriarch of Another World (Farnham, Surrey, England; Burlington, VT: Ashgate, 2012) Vaughn, Sally N. , 'St Anselm and the English Investiture Controversy', Journal of Medieval History 6.1 (1980), (61-86)

Vereker, Charles, The Development of Political Theory (London: Hutchinson University Library, Hutchinson University Library Politics, 1957)

Veyne, Paul , When Our World Became Christian, 312-394 (Cambridge; Malden, MA: Polity, 2010)

Ward, John Manning, Earl Grey and the Australian Colonies 1846-1857: A Study of SelfGovernment and Self-Interest (Melbourne: Melbourne University Press, 1958)

Ward, John Manning, et al., The State and the People: Australian Federation and NationMaking, 1870-1901 (Leichhardt, N.S.W.: Federation Press, 2001)

Warren, W. L. , Henry II (Berkeley: University of California Press, 2000)

Warren, W. L. , King John (London: Eyre Methuen, 2nd edition, 1978)

Watson, Frederick, and Australia Parliament Library Committee, Historical Records of Australia (Sydney: Library Committee of the Commonwealth Parliament, 1914)

White, William , A Charge to the Clergy of the Protestant Episcopal Church, in the

Commonwealth of Pennsylvania, Delivered in Christ Church, in the City of Philadelphia, on Wednesday, May 27, 1807 (Philadelphia: Printed at the office of the United States Gazette, 1807)

White, William, Memoirs of the Protestant Episcopal Church in the United States of America (New York: EP Dutton and Company, 1880)

White, William, and Richard G. Salomon, The Case of the Episcopal Churches in the United States Considered (Philadelphia: Church Historical Society, 1953)

Whitelock, D. , M. Brett and C. N. L. Brooke, Councils \& Synods: With Other Documents

Relating to the English Church: 1, A.D.871-1204 (Oxford: Clarendon, 1981)

Wilken, Robert Louis, The Christians as the Romans Saw Them (New Haven, Conn.; London: Yale University Press, 2nd edition, 2003)

Wilken, Robert Louis, The Spirit of Early Christian Thought: Seeking the Face of God (New Haven, Conn.: Yale University Press, 2003)

William of Malmesbury and David Preest, The Deeds of the Bishops of England (Gesta pontificum anglorum) (Woodbridge: Boydell Press, 2002)

Williams, G. H. W. , 'Christology and Church-State Relations in the Fourth Century', Church History 20.4 (1951), (3-33)

Williams, G. H. W. , 'Christology and Church-State Relations in the Fourth Century', Church History 20.3 (1951), (3-26)

Williams, Rowan, 'Does It Make Sense to Speak of pre-Nicene Orthodoxy ?', in Rowan Williams (ed.), The Making of Orthodoxy. Essays in Honour of Henry Chadwick, pp. 1-23 (Cambridge: Cambridge University Press, 1989)

Williams, Rowan , On Augustine (London: Bloomsbury Continuum, 2016)

Winroth, Anders , 'The Legal Underpinnings', in M. Rubin and W. Simons (eds.), The Cambridge History of Christianity. Christianity in Western Europe c. 1100-c. 1500, pp. 89-98 (Cambridge: Cambridge University Press, 2009)

Wolf, Victor , and Cardinal Deusdedit von Glanfell (Eds.), Collectio cononum, ed. Martinussic, Venice 1869: Originally Published in 1087 (Paderborn: 1905) 
Woolverton, John F. , 'Philadelphia's William White: Episcopalian Distinctiveness and Accommodation in the Post-Revolutionary Period', Historical Magazine of the Protestant Episcopal Church 43 (1974), (279-296)

Yates, Timothy , 'The Idea of a "Missionary Bishop" in the Spread of the Anglican Communion in the Nineteenth Century', Journal of Anglican Studies 2.1 (2004), (52-61) 